\title{
Trace and major element pollution originating from coal ash suspension and transport processes
}

\author{
Aleksandar Popovic ${ }^{\mathrm{a}, \mathrm{b}, *}$, Dragana Djordjevic ${ }^{\mathrm{b}, 1}$, Predrag Polic ${ }^{\mathrm{a}, \mathrm{b}, 1}$ \\ ${ }^{a}$ Department of Chemistry, University of Belgrade, PO Box 158, Belgrade 11001, Yugoslavia \\ ${ }^{\mathrm{b}}$ IChTM, Chemistry Center, Njegoseva 6, Belgrade 11000, Yugoslavia
}

Received 1 March 2000; accepted 20 November 2000

\begin{abstract}
Coal ash obtained by coal combustion in the "Nikola Tesla A" power plant in Obrenovac, near Belgrade, Yugoslavia, is mixed with water of the Sava river and transported to the dump. In order to assess pollution caused by leaching of some minor and major elements during ash transport through the pipeline, two sets of samples (six samples each) were subjected to a modified sequential extraction. The first set consisted of coal ash samples taken immediately after combustion, while the second set was obtained by extraction with river water, imitating the processes that occur in the pipeline. Samples were extracted consecutively with distilled water and a $1 \mathrm{M}$ solution of $\mathrm{KCl}$, $\mathrm{pH}$ 7 , and the differences in extractability were compared in order to predict potential pollution. Considering concentrations of seven trace elements as well as five major elements in extracts from a total of 12 samples, it can be concluded that lead and cadmium do not present an environmental threat during and immediately after ash transport to the dump. Portions of zinc, nickel and chromium are released during the ash transport, and arsenic and manganese are released continuously. Copper and iron do not present an environmental threat due to element leaching during and immediately after the coal ash suspension and transport. On the contrary, these elements, as well as chromium, become concentrated during coal ash transport. Adsorbed portions of calcium, magnesium and potassium are also leached during coal ash transport. (C) 2001 Elsevier Science Ltd. All rights reserved.
\end{abstract}

Keywords: Coal ash; Trace elements; Major elements; Leaching; Suspension transport

\section{Introduction}

Coal can be defined as combustible sedimentary rock, consisting of at least $50 \%$ of an organic fraction (Wood et al., 1983), and the remainder of which is an inorganic fraction that consists of mineral fragments and variously associated microelements. The content of inorganic elements can vary and, generally speaking, decreases the energetic value of coal.

The chemical and physical characteristics of coal are predetermined by the nature of precursor plants, the amount of inorganic materials and by the nature, intensity and duration of the biochemical and geochemical processes that are responsible for coal formation. All of the elements in coal

* Corresponding author. Department of Chemistry, University of Belgrade, PO Box 158, Belgrade 11001, Yugoslavia. Tel.: +381-11-635004; fax: +381-11-636-061.

E-mail address: apopovic@helix.chem.bg.ac.yu (A. Popovic).

${ }^{1}$ Tel.: +381-11-635-004; fax: +381-11-636-061. can be found in a variety of forms, determining the coal's technological, economical and ecological impact (Ruppert et al., 1995). Coal combustion in power plants generates large amounts of ash that is marginally used (construction industry, agriculture, glass production) (Nesic et al., 1997; Faber et al., 1995; Boccaccini et al., 1997) or, in most cases, stored more or less unprotected in the environment where it can represent a significant source of heavy metals, PAHs and other pollutants. In this paper, we have investigated microelement, and major element leaching during and immediately after coal ash transport to the dump of the "Nikola Tesla A" power plant in Obrenovac, Yugoslavia.

\section{Theoretical}

The inorganic coal component consists of discrete mineral fragments and variously associated trace elements. Coals from all parts of the world have been investigated, and almost all naturally occurring elements have been 
found. In US coals, 79 elements have been found, starting from carbon (63\% average content). The most abundant heavy metal is lead (11 ppm average), while ruthenium and osmium have been detected at trace levels only (1 ppb) (Finkelman, 1993). In coal of the Upper Silesia Basin, major components of mineral matter are clay minerals and carbonates (Bojarska and Bzowski, 1995). In coal samples from the West Transbaikal region, a detailed investigation of trace elements was performed, revealing the various types of their associations (Povarenykh and Meitov, 1995). It was found, e.g., that arsenic, cobalt and mercury are most commonly associated with pyrite, while lead, cadmium and selenium are associated with the organic phase and non-pyrite sulfides.

A series of physico-chemical transformations takes place during coal combustion in power plants, often changing solubility and association patterns of various elemental species. Moreover, the elements feature various distribution patterns among the mineral fractions obtained after coal combustion, often completely different, if compared to the original associations. It has been established that with the decrease of ash particle size, the concentrations of arsenic, copper, molybdenum, lead and zinc increase (MartinezTarazona and Spears, 1996). While quartz is carried through to the fly ash, pyrite and carbonates make a greater contribution to the bottom ash (Martinez-Tarazona and Spears, 1996). In coal ash obtained by the combustion of Nigerian coal, most of the elements examined had enrichment factors $<1$, while arsenic, iron, hafnium, sodium and titanium had enrichment factors ranging from 1 to 10 (Ewa et al., 1996). Also, some of the elements, like mercury, bromine and selenium, are predominantly evaporating. The environmental impact of coal ash production has at least two aspects: (a) emission and deposition of enormous amounts of coal ash, polluting air, water and soil with ash particles (including the problem of huge ash dumps); (b) leaching of microelements (including toxic heavy metals), but also major cations and anions from ash by atmospheric and surface waters.

After coal combustion, coal ash is usually stored in huge coal ash dumps, either in dry or wet state. Storage of wet coal ash usually protects from wind spreading, but decreases the time necessary for leaching of various elements (Iturbe et al., 1996). This leaching can be destructive to life forms, as it was shown in Lake Velenje in Slovenia, where ash was stored, causing death of most of the present life forms due to extremely increased alkalinity of water (Tamse, 1995). In addition, it can

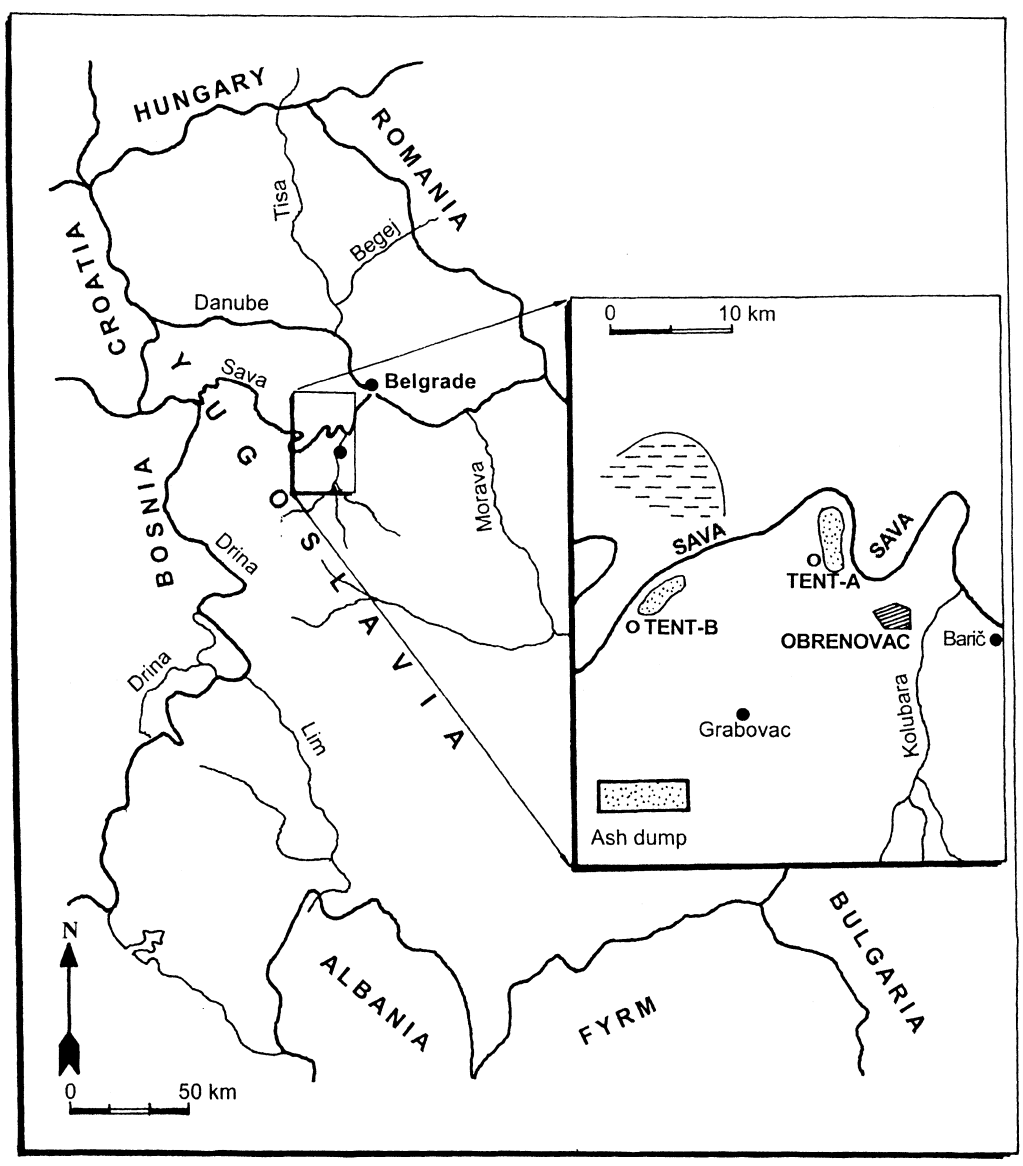

Fig. 1. Power plants in Obrenovac, near Belgrade (Yugoslavia). 
Table 1

Concentrations of trace elements after three extraction steps (ppm)

\begin{tabular}{|c|c|c|c|c|c|c|c|c|}
\hline Extraction step & Sample & $\mathrm{Cr}$ & $\mathrm{Ni}$ & $\mathrm{Cu}$ & $\mathrm{Zn}$ & As & $\mathrm{Cd}$ & $\mathrm{Pb}$ \\
\hline 1st $\left(\mathrm{H}_{2} \mathrm{O}\right)$ & Filter ash & $2.96 \pm 0.64$ & $0.28 \pm 0.04$ & $0.00 \pm 0.00$ & $0.00 \pm 0.00$ & $2.61 \pm 0.79$ & $0.00 \pm 0.00$ & $0.00 \pm 0.00$ \\
\hline 1st $\left(\mathrm{H}_{2} \mathrm{O}\right)$ & Treated ash ${ }^{\mathrm{a}}$ & $0.00 \pm 0.00$ & $0.00 \pm 0.00$ & $0.00 \pm 0.00$ & $0.06 \pm 0.06$ & $5.05 \pm 1.14$ & $0.00 \pm 0.00$ & $0.00 \pm 0.00$ \\
\hline 2nd (KCl) & Filter ash & $1.84 \pm 0.34$ & $1.06 \pm 0.66$ & $0.57 \pm 0.11$ & $1.51 \pm 0.33$ & $11.3 \pm 0.4$ & $0.00 \pm 0.00$ & $0.00 \pm 0.00$ \\
\hline 2nd ( $\mathrm{KCl})$ & Treated ash ${ }^{a}$ & $2.16 \pm 0.45$ & $1.05 \pm 0.49$ & $0.57 \pm 0.09$ & $0.84 \pm 0.28$ & $9.08 \pm 0.88$ & $0.00 \pm 0.00$ & $0.00 \pm 0.00$ \\
\hline 3rd (HCl) & Filter ash & $24.2 \pm 6.0$ & $14.0 \pm 3.3$ & $5.68 \pm 0.62$ & $9.69 \pm 3.37$ & $3.05 \pm 1.00$ & $0.00 \pm 0.00$ & $0.00 \pm 0.00$ \\
\hline 3rd ( $\mathrm{HCl})$ & Treated ash ${ }^{\mathrm{a}}$ & $24.8 \pm 5.6$ & $14.5 \pm 4.6$ & $6.11 \pm 0.48$ & $9.80 \pm 3.87$ & $6.81 \pm 1.64$ & $0.00 \pm 0.00$ & $0.00 \pm 0.00$ \\
\hline
\end{tabular}

a Previously leached with water from river Sava (see text).

jeopardize water resources and cause radioactive contamination (Vukovic et al., 1996).

\section{Location}

Approximately $70 \%$ of the total energy production in Serbia is obtained from its seven coal power plants, having a combined installed power of 5766 MW (Canak-Nedic et al., 1997). All seven of them are located in the vicinity of large coal mines. The second largest of the mentioned seven power plants is the power plant "Nikola Tesla A" (TENTA), located on the bank of the Sava river, in Obrenovac, 42 $\mathrm{km}$ upstream from the Yugoslav capital Belgrade (Fig. 1). It was built in 1970 and produces between 2.2 and $2.5 \times 10^{9}$ $\mathrm{kg}$ of coal ash per year (Canak-Nedic et al., 1997). Coal ash is transported to the dump after being suspended in the water taken from the Sava river, in the approximate ratio $1: 10$. The dump has an area of $4 \mathrm{~km}^{2}$ and consists of three sections: cassette 1 , with an area of $1.30 \mathrm{~km}^{2}$, which was filled from 1974 to 1982 ; cassette $3\left(1.30 \mathrm{~km}^{2}\right)$, filled from 1982 to 1990 ; and cassette $2\left(1.30 \mathrm{~km}^{2}\right)$, which has been in use since 1990.

Ash obtained by coal combustion in the "Nikola Tesla A" power plant was examined from the ecochemical standpoint by the authors of this paper (Polic et al., $1998 \mathrm{a}, \mathrm{b})$. They have found that major pollutants originating from the ash transport and dumping process are chromium, arsenic and nickel. Concerning trace element associations, these authors have found that nickel and chromium are primarily associated with magnesium aluminosilicates, whereas copper, arsenic and lead are associated with both calcium and magnesium aluminosilicates (Popovic et al., 1998). Oxides of iron and manganese seem to be the dominant substrates of chromium and nickel (Polic et al., 1998a).

While previous work done on samples from this power plant was aimed at establishing major associations and leaching characteristics of trace and major elements, this particular investigation was the first one addressing actual pollution occurring during coal ash suspension and transport processes.

\section{Experimental}

Twelve ash samples were analyzed - six filter ash samples taken after coal combustion but before its suspension and six samples of filter ash extracted with water from the Sava river - in order to imitate leaching processes occurring in the pipeline. The samples were sequentially extracted with distilled water, $1 \mathrm{M}$ solution of potassium chloride, $\mathrm{pH} 7$ and $\mathrm{HCl}$ solution of $\mathrm{pH} 3$. Extractions were performed by mixing for $18 \mathrm{~h}$ in bottles at $20^{\circ} \mathrm{C}$. The solid:liquid ratio was 1:10. After both extraction steps, the residues were washed with distilled water, and the combined extracts and washings were analyzed. Extractions of filter ash samples with Sava river water were performed under the same conditions which were used for sequential extraction (mixing for $18 \mathrm{~h}$ in bottles at $20^{\circ} \mathrm{C}$ with a solid:liquid ratio of 1:10).

The analyses of the combined extracts and washings after each extraction step (concentrated, if necessary) were performed by atomic absorption spectroscopy ("SpectrAA20 + Varian"). The following wavelengths were used: 285.2 $\mathrm{nm}(\mathrm{Mg}), 766.5 \mathrm{~nm}(\mathrm{~K}), 422.7 \mathrm{~nm}(\mathrm{Ca}), 357.9 \mathrm{~nm}(\mathrm{Cr}), 279.5$ $\mathrm{nm}(\mathrm{Mn}), 248.3 \mathrm{~nm}(\mathrm{Fe}), 232.0 \mathrm{~nm}(\mathrm{Ni}), 324.7 \mathrm{~nm}(\mathrm{Cu})$, $213.9 \mathrm{~nm}(\mathrm{Zn}), 193.7 \mathrm{~nm}(\mathrm{As}), 228.8 \mathrm{~nm}(\mathrm{Cd}), 217.0 \mathrm{~nm}(\mathrm{~Pb})$.

Table 2

Concentrations of major elements after three extraction steps (ppm)

\begin{tabular}{|c|c|c|c|c|c|c|}
\hline Extraction step & Sample & $\mathrm{Ca}$ & $\mathrm{Mg}$ & $\mathrm{K}$ & $\mathrm{Mn}$ & $\mathrm{Fe}$ \\
\hline 1st $\left(\mathrm{H}_{2} \mathrm{O}\right)$ & Filter ash & $2190 \pm 120$ & $1.11 \pm 0.21$ & $89.7 \pm 11.4$ & $0.60 \pm 0.10$ & $0.00 \pm 0.00$ \\
\hline 1st $\left(\mathrm{H}_{2} \mathrm{O}\right)$ & Treated $\operatorname{ash}^{\mathrm{a}}$ & $800 \pm 134$ & $0.32 \pm 0.12$ & $41.0 \pm 21.1$ & $0.51 \pm 0.12$ & $4.69 \pm 0.74$ \\
\hline 2nd (KCl) & Filter ash & $8850 \pm 450$ & $1960 \pm 90$ & N.A. & $3.31 \pm 0.41$ & $9.76 \pm 1.11$ \\
\hline 2nd (KCl) & Treated ash ${ }^{\mathrm{a}}$ & $8860 \pm 320$ & $1882 \pm 180$ & N.A. & $3.54 \pm 0.64$ & $6.71 \pm 0.64$ \\
\hline 3rd (HCl) & Filter ash & $1110 \pm 130$ & $141 \pm 24$ & $452 \pm 36$ & $60.3 \pm 7.3$ & $132 \pm 11$ \\
\hline $3 \mathrm{rd}(\mathrm{HCl})$ & Treated $\operatorname{ash}^{\mathrm{a}}$ & $1010 \pm 210$ & $148 \pm 41$ & $367 \pm 47$ & $58.9 \pm 9.4$ & $122 \pm 28$ \\
\hline
\end{tabular}

${ }^{a}$ Previously leached with water from river Sava (see text). 


\section{Results}

Concentrations of examined elements in extracts are shown in Tables 1 and 2.

\section{Discussion}

Out of seven microelements and five major elements examined, only lead and cadmium were not detected in any of the extracts. Other elements revealed the following behavior.

Chromium is one of the elements that is previously found to be one of the major pollutants, considering "exchangeable" fractions only (Polic et al., 1998b). Our results have shown that adsorbed chromium is already being released during the suspension transport to the dump. However, if we compare concentrations extracted by $\mathrm{KCl}$, the extractability increases during transport. This might be caused by chromium originating from river water, the pipeline or from readsorbed chromium that has already been extracted from the ash (Apak et al., 1998).

Water-extractable nickel shows properties similar to those of chromium. Nickel was found in small amounts only in the coal ash sample taken before its transport; hence, it becomes released during transport. There is no significant change in $\mathrm{KCl}$-extractable nickel (although the waterextracted $\mathrm{Ni}$ fraction should affect the amount of $\mathrm{KCl}-$ extracted $\mathrm{Ni}$ in the filter sample), proving that this fraction of nickel is not a significant polluting factor during the various phases of coal ash transport.

Water-extractable copper is not detectable in any sample. However, the $\mathrm{KCl}$-extractable copper content is similar in both filter- and river-water-treated ash.

Zinc, being insignificantly desorbed by water, shows "expected" behavior in the case of $\mathrm{KCl}$ extraction: filter ash contains more extractable zinc than "treated" samples, suggesting that roughly half of the ion-exchangeable zinc is released during the coal ash transport to the dump.

Another specific case is the behavior of arsenic: it can be extracted from all samples by water extraction already. There is also an unexpected increase of water-extractable arsenic after river water leaching. Moreover, if we add the fact that the sums of both arsenic fractions are practically the same for filter ash and for river-water-leached ash $(2.6+11.3=5.0+9.1=$ approximately $14 \mathrm{ppm} ;$ Table 1$)$, we can come to the conclusion that river water leaching (at least under laboratory conditions) just increases the mobility of arsenic, which then can be extracted (e.g., by distilled water and/or $\mathrm{KCl}$ ?). On the other hand, if river water acts as an additional source of arsenic (which is a more convincing explanation), the "14 ppm phenomenon" must be regarded as a pure coincidence.

Examined alkaline and earth alkaline major elements show similarity in their behavior: water-adsorbed fractions of calcium, potassium and magnesium are significantly leached during river water transport. However, river water extraction of coal ash did not have any influence on ionexchangeable fractions (two-phase) of magnesium and calcium (potassium was not analyzed because extraction was performed with $\mathrm{KCl}$ ).

The amount of water-extracted iron has increased after extraction with river water. This can be explained by adsorption of iron from river water (and during transport, from the pipeline) by the coal ash. However, extraction of both series of coal ash with $\mathrm{KCl}$ showed expected behavior, i.e., previous extraction of coal ash with river water has decreased the amount of leached ion-exchangeable iron, witnessing possible leaching of iron during transport processes. The result of these two opposite processes is that ash deposited on the dump becomes enriched in iron compounds (probably deposited from river water used for suspension, surface water, extracted from the pipeline, etc.).

The behavior of iron might explain the unexpected (extractable) $\mathrm{Cr}$ and $\mathrm{Cu}$ increase after dumping - the increase of extractable Fe (after river water treatment) most certainly originates from river water, surface water, etc., with $\mathrm{Cr}$ and $\mathrm{Cu}$ probably being associated (co-precipitated) with iron (hydroxide).

Finally, in the case of manganese, no effects of transportation processes on element extractability could be detected.

It should be noted that in the third phase of sequential extraction, concentrations of trace and major elements examined did not change after river water treatment (with the exception of calcium). This is expected because of neutral or close-to-neutral $\mathrm{pH}$ of river water. However, concentrations found in extracts witness possible contamination and leaching of elements during, e.g., occasional and 'off the record', but necessary (sometimes twice per year, sometimes once in several years), washings of pipelines with $\mathrm{HCl}$ (in order to dissolve precipitated insoluble compounds, mostly carbonates).

Table 3

Estimation of pollution by examined trace and major elements during coal ash/river water suspension transport to the dump

\begin{tabular}{lll}
\hline & $\begin{array}{l}\text { Estimated amount } \\
\text { of element leached } \\
\text { (dry ash basis, ppm) }\end{array}$ & $\begin{array}{l}\text { Estimated annual amount } \\
\text { of element leached }(\mathrm{t})\end{array}$ \\
\hline $\mathrm{Mg}$ & 0.79 & $1.74-1.98$ \\
$\mathrm{~K}$ & 48.7 & $107.1-121.8$ \\
$\mathrm{Ca}$ & 1390 & $3060-3480$ \\
$\mathrm{Cr}$ & 2.64 & $5.81-6.60$ \\
$\mathrm{Mn}$ & N.A. & N.A. \\
$\mathrm{Fe}$ & N.A. & N.A. \\
$\mathrm{Ni}$ & 0.28 & $0.62-0.70$ \\
$\mathrm{Cu}$ & N.A. & N.A. \\
$\mathrm{Zn}$ & 0.64 & $1.41-1.60$ \\
$\mathrm{As}$ & N.A. & N.A. \\
$\mathrm{Cd}$ & 0.00 & 0.00 \\
$\mathrm{~Pb}$ & 0.00 & 0.00 \\
\hline
\end{tabular}




\subsection{Quantitative estimation of pollution}

Based on concentration differences of the examined elements in first two phases of sequential extraction, as well as on the fact that "Nikola Tesla A" power plant is producing $2.2-2.5 \times 10^{9} \mathrm{~kg}$ of coal ash annually, the amounts of elements that are leached during ash transport to the dump can be estimated. Results of such estimations are shown in Table 3.

As it can be seen from Table 3, during coal ash transport to the dump, the largest pollutant is chromium (5.8-6.6 $\mathrm{t}$ annually), while considerably smaller amounts of zinc (1.4-1.6 t annually) and nickel are leached (0.6$0.7 \mathrm{t}$ annually). Cadmium, lead, arsenic and copper are apparently not polluting the environment considering coal ash transport processes only. Calcium seems to be the largest pollutant originating from coal ash transport processes (up to almost $3500 \mathrm{t} /$ year), while approximately $100 \mathrm{t}$ of potassium and fewer than $2 \mathrm{t}$ of magnesium are also released each year by the abovementioned mechanisms.

\section{Conclusions}

(1) Cadmium and lead are apparently not extracted from the samples examined, proving that during and immediately after coal ash suspension transport, the extraction of these two elements is insignificant and does not represent an environmental threat. This can be stated for copper, also.

(2) Zinc, chromium, nickel and arsenic are elements which become significantly extracted during transport, with arsenic continuously being extracted even after dumping.

(3) There are no changes in the extractability of manganese during or immediately after the transport. This element is partially being leached during and after transport of coal ash.

(4) Ash deposited on the dump becomes enriched in iron compounds (probably deposited from river water used for suspension, surface water, extracted from the pipeline, etc.).

(5) Portions of absorbed (water-leachable) calcium, potassium and magnesium become extracted during transport, while there is no change in ion-exchangeable fractions of calcium and magnesium.

(6) Up to almost $3500 \mathrm{t}$ of calcium, more than $100 \mathrm{t}$ of potassium and up to $2 \mathrm{t}$ of magnesium are being released annually from coal ash during coal transport process.

(7) The largest pollutant among trace elements is chromium (around $6 \mathrm{t}$ /year), while around $1.5 \mathrm{t}$ of zinc, as well as between 600 and $700 \mathrm{~kg}$ of nickel, are also being leached each year, due to transport processes only.

\section{References}

Apak R, Tutem E, Hugul M, Hizal J. Heavy metal cation retention by unconventional sorbents (red muds and fly ashes). Water Res 1998; 32:430-40

Boccaccini AR, Bucker M, Bossert J, Marszalek K. Glass matrix composites from coal fly ash and waste glass. Waste Manage 1997;17:39-45.

Bojarska K, Bzowski Z. Major chemical components and mineralogical character of the inorganic matter of energetic coals from the east part of Upper Silesia coal basin (Poland). Proc 12th Annu Int Pittsburgh Coal Conf. Pittsburgh, 1995. pp. 511-6.

Canak-Nedic A, Gavrilovic M, Pavlovic N, Nozinic J, Stankovic N, Kuzmanovic U, Nedic M. Coal ash dumps - environmental aspects. Energy-Econ-Ecol 1997;2:63-5.

Ewa IOB, Adetunji J, Elegba SB. Determination of trace elements in Nigerian coal ash by instrumental neutron activation analysis. Hazard Subst Control, A 1996;31:1089-100.

Faber W, Lenz U, Paeffgen H, Moehlenbruch N. Soil ameliorant and liming agent based on lignite ash. Ger Offen De 1995;19,551,319.

Finkelman RB. Trace and minor elements in coal. Organic geochemistry. New York, NY: Plenum, 1993. pp. 593-607.

Iturbe R, Cruickshank C, Vega E, Silva AE. Solubility and transport of arsenic in coal ash. Proc 3rd Tailings Mine Waste, Rotterdam. 1996; $305-7$.

Martinez-Tarazona RM, Spears AD. The fate of trace elements and bulk materials in pulverized coal combustion in a power station. Fuel Process Technol 1996;41:79-92.

Nesic Lj, Zbogar Z, Bosiljcic R, Kisic D. The use of coal ash. EnergyEcon-Ecol 1997;2:66-9.

Polic P, Grzetic I, Djordjevic D, Popovic A, Markovic D. Association forms of heavy metals in fly ash from power plants. Proc 2nd Transp Chem Transform Troposphere, Garmisch-Partenkirchen. 1998a. pp. 6-54.

Polic PS, Grzetic IA, Popovic AR, Djordjevic DS, Kisic DM, Zbogar ZM. Microelements from coal ash: exchangeable fractions. Chem Ind 1998b; $52: 12-8$

Popovic A, Djordjevic D, Grzetic I, Polic P. Calcium and magnesium leaching and associated microelement pollution from coal ash. Proc 16th River Estuarine Pollut, Fossil Fuel Environ Qual, Derby. 1998. p. 45 .

Povarenykh MYu, Meitov ES. Investigation of the forms of occurrence of rare and trace elements in brown coals of Tarbagatai field (West Transbaikal Region). Litol Polezn Iskop 1995;4:402-14.

Ruppert LF, Hower JC, Eble CF. Significance of the modes of occurrence of arsenic in coal. Proc 12th Annu Int Pittsburgh Coal Conf. 1995. pp. $1152-6$.

Tamse M. Deposition of ash, slag and products of additive desulfurization from the power plant Sostanj into the barrier between the lakes Velenje and Druzmirje. Rud-Metal Zb 1995;42:59-68.

Vukovic Z, Mandic M, Vukovic D. Natural radioactivity of ground waters and soil in the vicinity of the ash repository of the coal-fired power plant "Nikola Tesla" A-Obrenovac (Yugoslavia). J Environ Radioact 1996; 33:41-8.

Wood GH, Kehn TM, Carter MD, Colbertson WC. Coal resource classification system of the US Geological Survey. US Geol Surv Circ 1983;891. 